\title{
Lessons of Success from False Creek South and Granville Island
}

\author{
Don Alexander \\ Vancouver Island University
}

\section{Résumé}

Les années 1970 ont été une période politique exceptionnellement fertile en matière de logement et d'urbanisme au Canada. Deux manifestations sont la création du quartier du centre-ville unique de False Creek South à Vancouver, en Colombie-Britannique. et Granville Island, un quartier des arts et des marchés publics qui est entouré par le quartier. Cet article examine les facteurs qui ont permis à ces projets de planification innovants de se concrétiser, les raisons pour lesquelles leur réplication peut être difficile, mais aussi les signes indiquant que de nouvelles circonstances peuvent émerger et rendre de nouvelles innovations possibles.

Mots-clés: False Creek South, Granville Island, Vancouver, planification innovante

\section{Abstract}

The 1970s were an exceptionally fertile policy period with respect to housing and community planning in Canada. Two manifestations are the creation of the unique inner-city neighbourhood of False Creek South in Vancouver, B.C. and Granville Island, an arts and public market precinct that is surrounded by the neighbourhood. This article examines the factors that enabled these innovative planning projects to occur, why replicating them might be challenging, and what new innovations may be emerging.

Keywords: False Creek South, Granville Island, Vancouver, innovative planning

\section{INTRODUCTION}

As Leonie Sandercock (1998) has noted, there is a "noir" side of planning and, like planners everywhere, Canadian planners or their surrogates have created their share of "planning disasters." The displacement of First Nations, the tragedy of Africville where residents of an African-Canadian community were dispossessed and dispersed throughout the greater Halifax area, the warehousing of the poor and people of colour in Regent Park and other housing "projects," the encouragement of sprawl after World War II, and the efforts to wipe out Chinatown and Strathcona through "urban renewal" and freeway-mania; all these come to mind. (Hodge, Gordon, \& Shaw, 2020; Alexander, 2019)

And yet, alongside these terrible errors, Canadian urbanists have also produced some wonderful successes. In this context, I define "success" as the attainment of most of the following conditions: the achievement of socio-economic diversity; the achievement of diverse affordable housing; successful mixed use; an abundance of amenities, such as green and public space; opportunities for

Canadian Planning and Policy/Aménagement et politique au Canada, Volume 2021, pages 17-35.

This work is licensed under a Creative Commons Attribution 4.0 International License.

ISSN 2562-122X

DOI 10.24908/cpp-apc.v2021i01.14164 


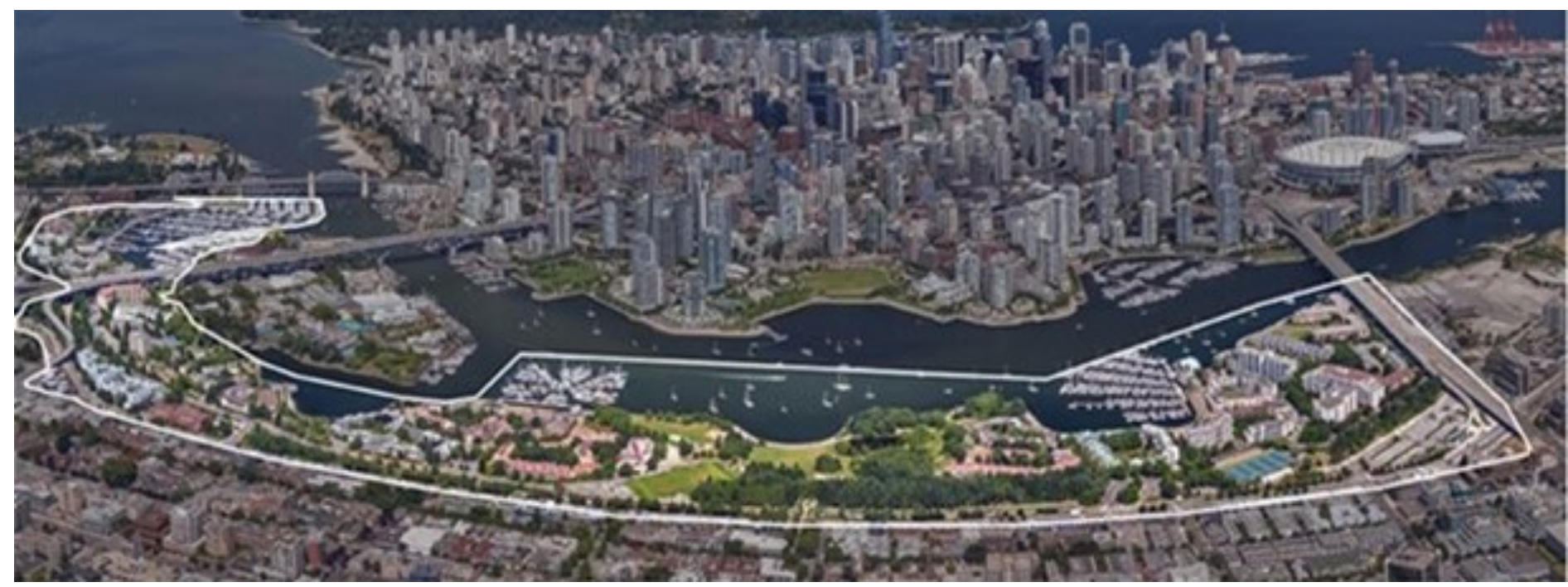

Figure 1. False Creek South and Granville Island (Source: City of Vancouver, with permission)

community interaction, and at least some continuity of historical architectural forms.

Two cases that come to mind as successes, and are widely regarded as such, are the False Creek South neighbourhood of Vancouver and its adjacent public market/arts and theatre district at Granville Island (Beasley, 2019). ${ }^{1}$ Neither could easily be replicated today (Ley, 2019), for a variety of reasons. However, such achievements in perhaps altered form are not beyond attainment. To assess whether such projects are possible today and under what conditions, one must first understand what made them possible in the first place. This will also help us to identify new conjunctures of circumstances that might make positive change possible and enable us to make the most of such opportunities if they arise.

\section{False Creek South Creek and Granville ISLAND - AN OVERVIEW}

False Creek South is an inner-city neighbourhood of nearly 5,600 people on 55 hectares (136 acres) between the Cambie Street Bridge and the Burrard
Bridge on the south side of False Creek, bounded on the north side by the Creek and on the south by Sixth Avenue. It exists on the traditional unceded territory of the Musqueam, Squamish, and TsleilWaututh First Nations. It was developed in five phases, each with its own development plan, between 1975 and 1989 under the direct leadership of Vancouver City Council, with the staunch support of the Canada Mortgage and Housing Corporation (CMHC) and, in the early years, the Ministry of State for Urban Affairs (Hulchanski, 1984; City of Vancouver Planning Department, 2017).

The neighbourhood is characterized by mixed income and tenure features, which makes it unusual. The urban form is one of medium density, with townhouses and apartment-style buildings surrounded by abundant greenspace. Including the adjacent community of Fairview, False Creek South has 103 people per hectare, whereas the population density of Dunbar-Southlands is 24 persons per hectare (City of Vancouver, 2020). At the other end of the spectrum from Dunbar-Southlands is

\footnotetext{
${ }^{1}$ Social scientists whose assessment lends support to these developments being successful include Andrejs Skaburskis, Jacqueline Vischer (1980, 1986), David Hulchanski (1984), and David Ley (1989, 2019). This assessment has been supplemented by the work of the numerous planners cited throughout this article.
} 


\section{Lessons of Success from False Creek South and Granville Island}

Yaletown's population density at 130.6 persons per hectare (Smedman, 2013). Thus, False Creek South exhibits a relatively high population density. While there are a few higher buildings, none take the form of point towers. False Creek South is also unusual in that the housing units are not arrayed along streets for the most part, but around open space (Vischer Skaburskis, 1980).

The proposed development of Senákw west of the Burrard Bridge would mark a radical departure from the urban form of False Creek South (Chan, 2019). The Squamish Nation, having regained control of their old reserve land of 4.73 hectares (11.7 acres), is currently planning, in partnership with Westbank Developments, to build a high-rise precinct of 6,000 homes which will greatly transform the character of the neighbourhood on the west side. This will have implications for shared facilities, such as the False Creek Community Centre at Granville Island, and will also generate the need for more schools and daycare facilities. (Chan, 2019; N. Edelson, personal communication, December 3, 2020). ${ }^{2}$

Granville Island, which is also on unceded Coast Salish land and was developed in the 1970s at the same time as the first phases of False Creek South, is a market and cultural precinct on 14 hectares (35 acres) underneath the Granville Street Bridge, surrounded by the western portion of False Creek South. Built on former industrial land, it features an eclectic mix of land uses including a cement plant, a shipbuilding and repair enterprise along with newer elements such as a public market, shops, theatres, a brewpub, hotel, waterpark, arts and crafts studios and, until recently, an arts college. In addition, there is a greenfield park and plazas where people can gather and listen to buskers. It is under federal jurisdiction, administered through the (CMHC) originally through a Granville Island Trust, whose

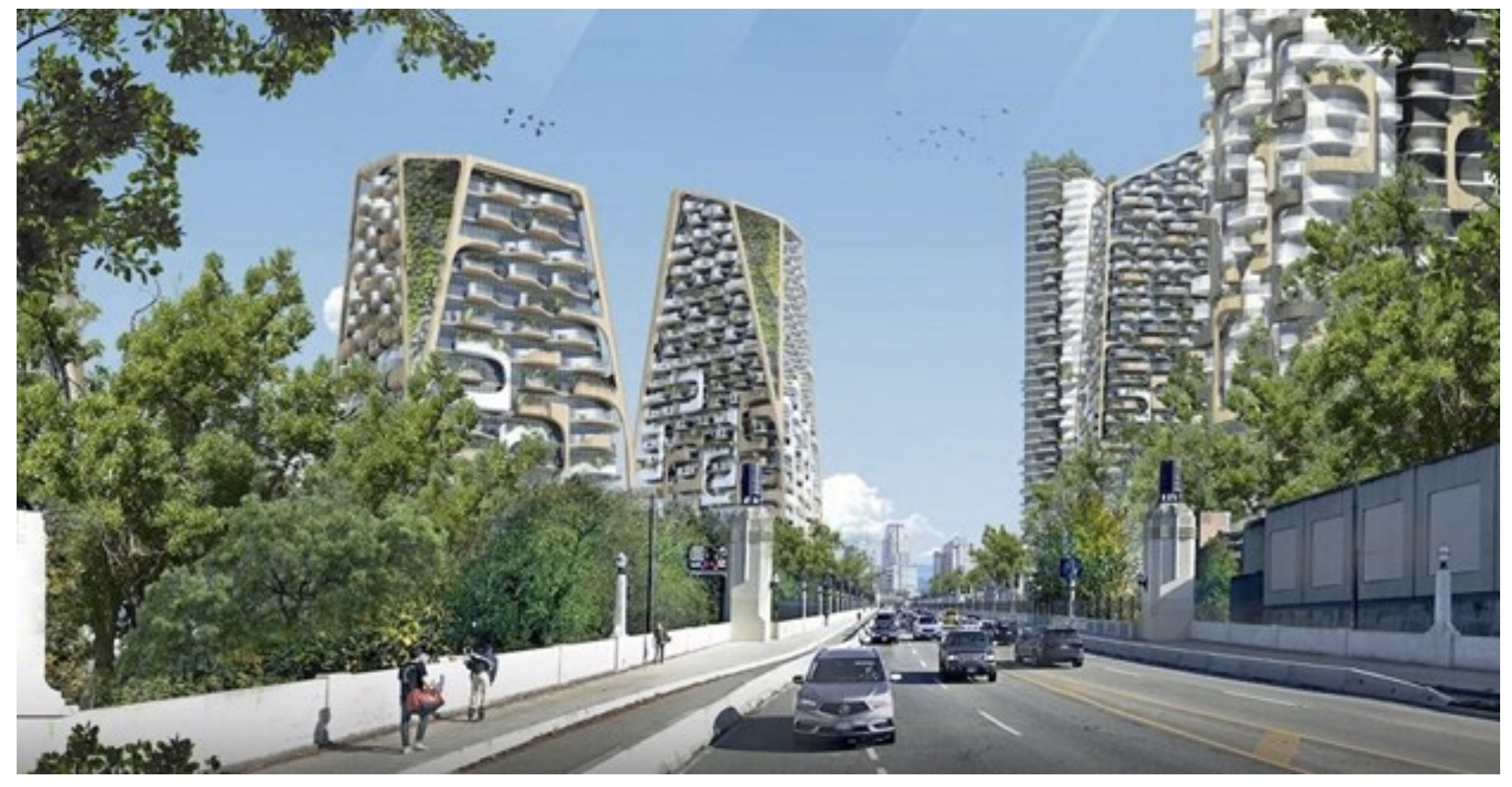

Figure 2. Artist's rendering of proposed Senáḱw development (Source: Daily Hive, with permission)

\footnotetext{
${ }^{2}$ The new development is still in negotiation with the City but, if realized, will be up to 25 times the density of False Creek South (Chan, 2019).
} 
authority has now been transferred to the multistakeholder Granville Island Council (Lippa, personal communication, December 18, 2019). It has been described as "one of the world's great public spaces" by the Project for Public Spaces. This New York-based NGO, perhaps the leading analyst of public space, has noted that Granville Island's market is one of most successful in North America (Project for Public Spaces, 2015) and is a major attraction for local residents and tourists alike.

All stores and arts and craft studios on the island are one of a kind, though the latter have to some degree been supported through a cross-subsidy model, with revenues generated from higher lease spaces help finance the development, operation and maintenance of lower lease spaces (Lippa, personal communication, December 18, 2019). Despite this, the Island has been self-sufficient since it was given its original $\$ 20$ million grant in the 1970s, which the Island's senior planner attributes to it being such

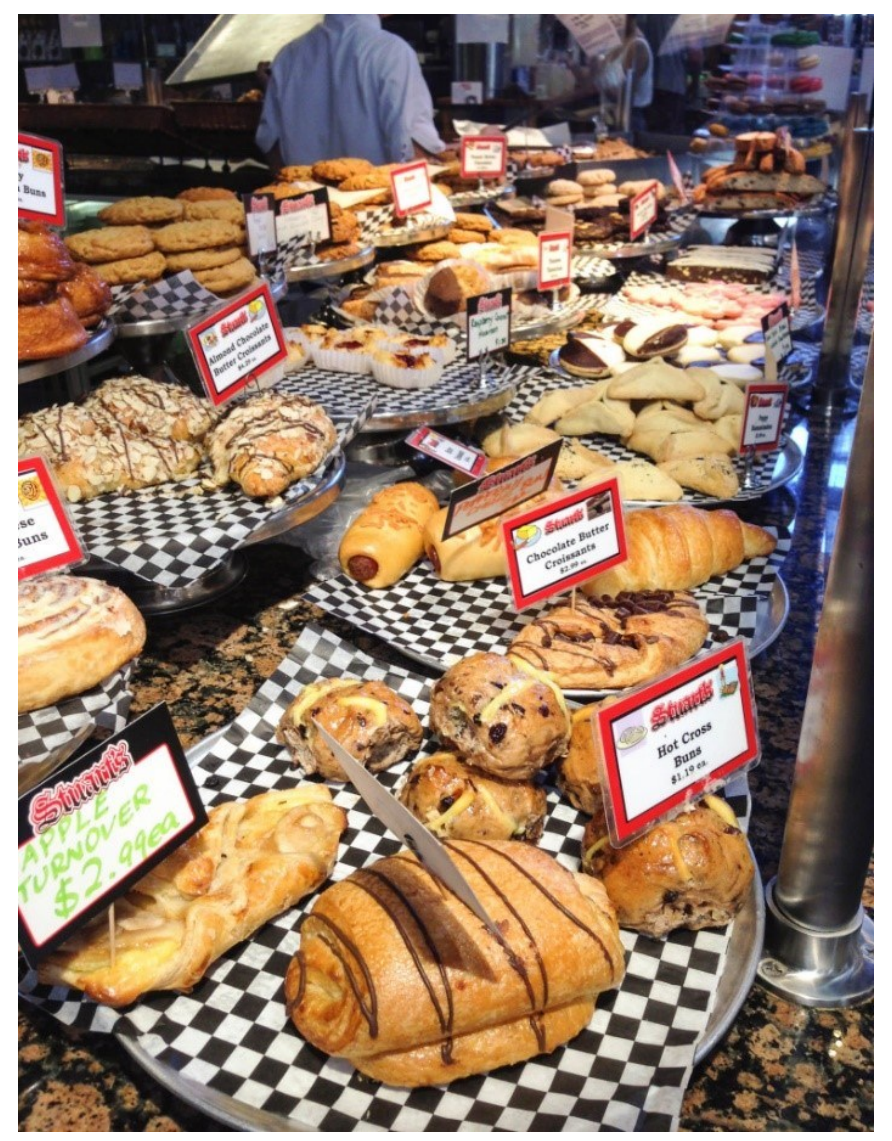

a commercial and cultural "magnet" (Lippa, personal communications, June 8, 2018, December $18,2019)$. With the market at its heart, the Island as a whole is a unique place, drawing large numbers of residents year-round and many tourists in the summertime (Bramham, 2014b; Gourley, 1988).

The Island is currently undergoing a major rethink. Its largest occupant, an arts and design university. has relocated to the False Creek Flats to be in closer proximity to other educational institutions (Chan, 2017). The challenge now is how to re-purpose the vacant space as well as to improve transit access (Bramham, 2014b). Indeed, the prioritization of pedestrians and cyclists over cars and tour buses is being reinforced by ending free parking and proposing to install an elevator down to the Island from the Granville Bridge, thus greatly improving access from a number of buses. Currently, only one bus directly serves the Island (Beasley, 2019; Lippa, personal communication, December 18, 2019; St. Denis, J. 2019).

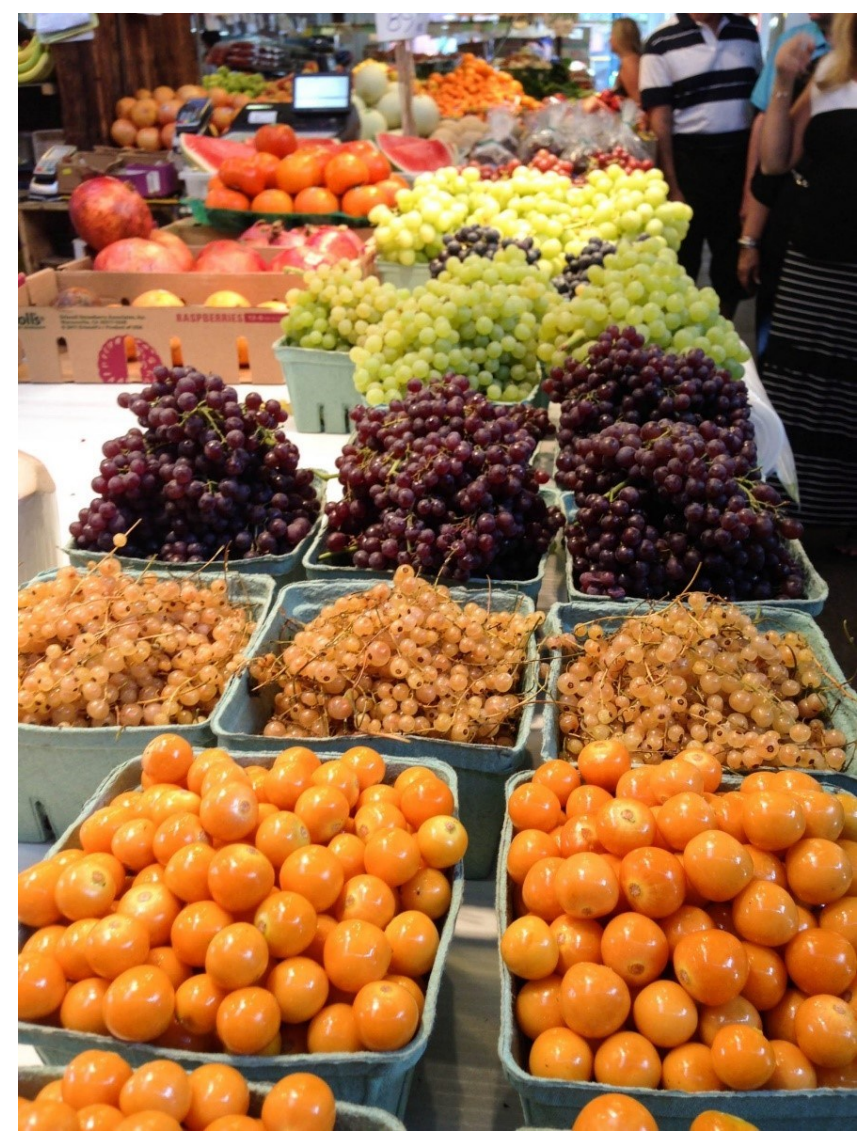

Figure 3 and 4. False Creek South and Granville Island (City of Vancouver, with permission) 


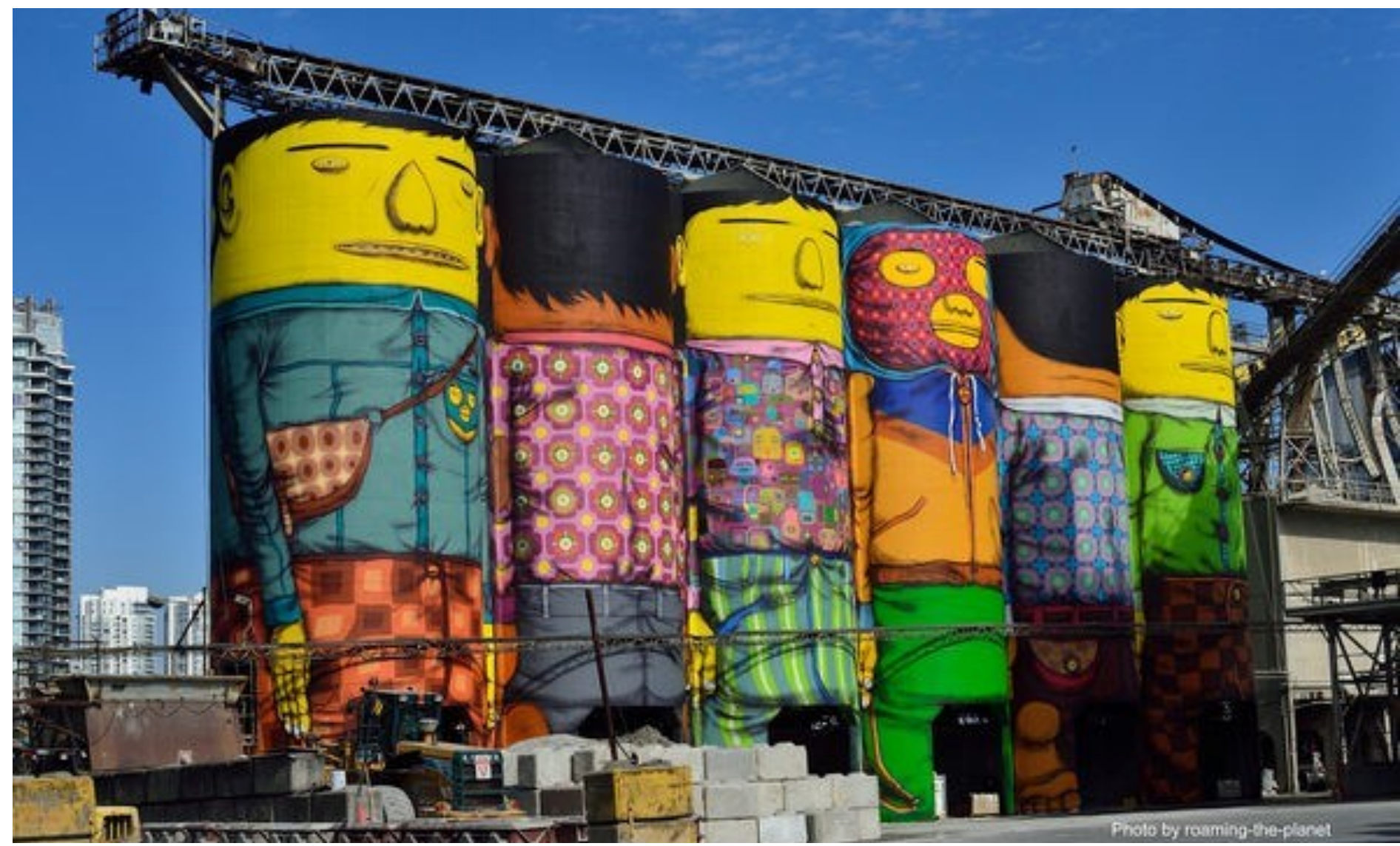

Figure 5. Granville Island Painted Cement Silos (Source: Atlas Obscura, with permission)

\section{How Did False South Creek and Granville ISLAND COME TO BE?}

\section{Ideas in Motion: Time, Era and Circumstances}

Both False Creek South and Granville Island were the product of the same era, one which felt pregnant with possibilities and where there was an openness to fresh ideas and approaches on the part of all levels of government (Ley, 2014). This was the period of the early to late 1970s. The social movements of the 1960s had created a social energy for change and a sense that innovative approaches to social and environmental problems were both necessary and desirable. The energy of the 1960s had filtered into the design professions. Idealistic planners and architects were seeking to tackle problems in new ways to make the world a better place (Hardwick, 1994). Christopher Alexander, an architect whose Pattern Language (Alexander, Ishikawa \& Silverstein, 1977) found many followers and helped influence the design of False Creek South (Hardwick, 1994; Phillips, 1993; Ley, 1987). ${ }^{3}$ More importantly, perhaps, this period represented "the high point of the Canadian welfare state," before the accumulation of a massive federal deficit (Ley, 2019).

In 1971, under Prime Minister Pierre Trudeau, a new Secretary of State for Urban Affairs was created with Robert Andras in the post. Earlier, Paul Hellyer, Minister of Transportation, had exerted a positive influence in encouraging the federal focus on urban issues before resigning from cabinet over policy differences with the Prime Minister

\footnotetext{
${ }^{3}$ While Alexander's Pattern Language was not given full published expression until 1977, it was circulating in architectural and planning circles years before, and was anticipated in his earlier writings (Alexander, 1969).
} 


\section{Lessons of Success from False Creek South and Granville Island}

(Friendly, 2016; Alexander, 2019). What eventually killed the Secretary of State position was the growing resentment by the provinces that federal initiatives were beginning to encroach on their policy turf (Ley, 2019). ${ }^{4}$

\section{Key Players: Visionary Politicians and Other Champions}

Another key factor in the emergence of these success stories in the 1970s was the role of visionary politicians and champions. Ron Basford, Liberal MP for Vancouver-Centre from 1968 to 1979, who succeeded Andras as Minister of State for Urban Affairs (1972 to 1974), is widely credited with being the driving force behind the transformation of Granville Island, long a derelict industrial precinct, into a thriving public market and arts district. However, he in turn was inspired by the ideas of local innovator and gadfly, Alan Clapp (Bramham, 2015).

The initial impetus for the transformation of the Island (now connected to the mainland) is that the land, then owned by the National Harbours Board, was by the late 1960s a decrepit industrial eyesore. It was obvious that something needed to be done to restore it. It was then that $\mathrm{CMHC}$ took over ownership from the Harbours Board. Under Basford's leadership, it began to be re-envisioned as a "people place," while retaining its maritime and industrial heritage (Vancouver Heritage Foundation, 2018). Since the land was not owned by the City, Joost Bakker and Norman Hotson, the architects in charge of its revitalization, were not constrained by normal City of Vancouver guidelines such as separation of vehicular and pedestrian traffic. (Vancouver Heritage Foundation, 2018.).

In the case of False Creek South, the visionary was Walter Hardwick, a University of British Columbia geography professor and city council member from 1968 to 1974 (Ley, 2019; CityHallWatch, 2014). Hardwick was largely the brains behind The Electors Action Movement (TEAM) that swept into power in $1972 .{ }^{5} \mathrm{He}$ was the one with the vision for transforming False Creek South, a declining industrial zone, into a mixed-income residential neighbourhood, reflective of the range of incomes found within the region as a whole and with a diversity of tenure types (Ley, 1987). TEAM 1972 campaign material (as Ley, 1987, p.46) described the future False Creek as holding the potential to offer an example of "inner-city living at its best," and that its waterfront would feature "a continuous series of parks and marinas for all the people to enjoy."

With TEAM in office, Hardwick was instrumental in the creation of the Special Council Committee on False Creek (SCCFC), which guaranteed City Council members a direct role in shaping the neighbourhood. For councillors to play such a role was unusual. Once the City set its course, direction of the planning process was turned over to Stuart Sutcliffe, a manager with a strong record of accomplishment (Hardwick, 1994; Hulchanski, 1984). Hardwick (1994) notes that in the past, members of the city bureaucracy had set policy directions and expected City Council to rubberstamp those directions. TEAM's approach turned this on its head, with politicians providing policy leadership and turning implementation over to the bureaucrats.

Of course, none of this was straightforward. The City had been dithering for decades about what to do with False Creek, and a number of studies had been conducted about possibly converting what had become derelict industrial land into residential or other uses. As Hardwick (1994) writes:

\footnotetext{
${ }^{4}$ Not until the short-lived Liberal government of Paul Martin (2003-2006) did the urban file start to assume the same profile again (Friendly, 2016).

${ }^{5}$ The same year that TEAM was created in 1968, another party, the Coalition of Progressive Electors (COPE) was also established. Both had as their base young and middle-aged professionals with a different paradigmatic set of beliefs and values from those of the establishment. These two parties often cooperated on planning issues (Ley, 2019). The rise of these parties was emblematic of a nationwide urban reform movement that occurred in cities across Canada (Weaver, 2014; Magnusson \& Sancton, 1983).
} 


\section{Lessons of Success from False Creek South and Granville Island}

A project of students in geography and architecture at the University of British Columbia addressed the role of these central lands. Following socioeconomic and design analyses it was recommended that industrial uses be abandoned, and the area be integrated into the fabric of the city, with residential and commercial activities placed with a major waterfront park and recreation system. A land economic analysis concluded that the price of the industrial land was far lower than adjacent and commercial areas. Demographic analysis showed there was an expanding lifestyle cohort group that sought inner-city living opportunities some of which could not be met in the high-rise West End. Recreation studies illustrated how the water's edge could be drawn into the public domain to extend the public walkways that rimmed Stanley Park and English Bay. The recommendations of the students and academics were largely ignored by the civic politicians, planners, and developers. (p. 346).

However, some academics, like Hardwick, gradually began to move into the political arena and used this vision as part of the platform for the new party, TEAM. Between 1968 and 1972, their numbers on Council grew from two out of ten to a majority of eight, with one COPE member and one Non-Partisan Association (NPA) representative. At this point they were in a position to realize their dream. Also, the existing industries were no longer the "highest and best use" for the site. The fact that most of their leases expired in 1972 offered a convenient opportunity to conduct a long overdue "spring cleaning."

In the early 1970s, there were many competing visions for False Creek South - all park, a museum and cultural precinct, or a mixed residential and green space district. TEAM favoured the latter, and their rivals - the Non-Partisan Association (NPA), formerly the dominant party - oscillated between the first and second option, with votes on the fate of the area invariably following party lines. There were many inside and outside the city bureaucracy who

CIP-ICU \& ACUPP-APUCU were opposed to False Creek South's proposed redevelopment. As George Puil (as cited in Adams, 1972, p. 6), long-standing chair of the Vancouver Park Board, said at the time "It's there, it's in our hands, we think it should be parkland." A final challenge was that the land was highly contaminated by its history of industrial activity. As a result the most contaminated areas were turned into parkland.

\section{Inter-jurisdiction Collaboration}

In both False Creek South and Granville Island, interjurisdictional collaboration was a major precondition of success (Thompson, n.d.). For instance, the federal government, through $\mathrm{CMHC}$, offered the City a $\$ 10$ million low-interest loan to assist in the development of False Creek South and paid for much of the seawall to be created (Hulchanski, 1984). Much of the rest of the costs associated with developing infrastructure for the neighbourhood, such as for roads, sewers, and park fixtures, were able to be recovered by the City through leases and modest sales of land (Hulchanski, 1984). The province, under the NDP government of Dave Barrett, facilitated the City in acquiring the land. Despite initial differences, the City and the federal government came to an eventual rapprochement over the vision for Granville Island.

The creation of False Creek South also coincided with the period when the federal government extended massive support to the creation of housing co-operatives nationally through underwriting mortgages through CMHC. It also extended housing subsidies to low-income co-op households, which have expired in all False Creek South co-ops except one, and indeed are being phased out throughout the city (Ball, 2013; N. Edelson, personal communication, January 18,2020 ). As a result, coops were soon to be well-represented in the neighbourhood (Hulchanski, 1986; *RePlan, 2016). In fact, False Creek South boasts the highest concentration of co-ops in B.C. Currently, there are 614 co-op housing units in six separate complexes out of a total of 3,258 housing units in the neighbourhood (City of Vancouver Planning 
Department, 2017; *RePlan, 2016). In addition, there are 416 social housing units present, along with seniors' and special needs housing (City of Vancouver Planning Department, 2017; Hardwick, 1994).

\section{False Creek Development as a Major Shift in Planning Priorities}

False Creek South's development represented a major shift in planning priorities. As Ron Walkey (as cited in Phillips, 1993, p. 12) notes, the neighbourhood's development involved "a very important reversal in the traditional Vancouver land development process: namely that the kind of community that is desired should be determined first." This is closely related to the reaction against modernism initially precipitated by Jane Jacobs' (1961) publication of The Death and Life of Great American Cities. Modernism in planning and architecture is associated with Le Corbusier and others who sought to eradicate traditional citybuilding practices in favour of "clean-slate" planning with single-use residential towers conceived of as "machines for living," and often surrounded by parkland. Automobiles would be the dominant mode of transport and would be accommodated through major arterials and freeways. Buildings themselves were to lack ornamentation, and historic street-oriented mixeduse neighbourhoods were to be eliminated (Hall, 2014).

In his 1987 article in the Journal of Historical Geography, David Ley explicitly suggests that False Creek South was created in the postmodernist spirit of Jacobs and her successors. Postmodernism in planning and architecture refers to a rejection of the presumptions and design principles of modernism, and not to the radical subjectivism which suggests that there is not nor can there be a consensus on the nature of reality (Hodge, Gordon, \& Shaw, 2020; Ley, 2015). Early planning documents for False Creek South included quotations from Jacobs, planners Ian McHarg and Kevin Lynch, and urban sociologist Herbert Gans. A strong emphasis was placed on the human scale and quality of life to avoid the "towers in the park"

CIP-ICU \& ACUPP-APUCU aesthetic of Le Corbusier" (Beasley, 2019; Hardwick, 1994; Spaxman, 1994). It involved an explicit rejection of the "housing project" model where poor people were warehoused in single-use high-density developments away from street life and amenities. Instead, the politicians and planners were in favour of creating a genuine neighbourhood, one that integrated different tenure types - social housing, subsidized rentals, housing co-operatives, and strata units - in adjacent complexes with no great contrast in their appearance. Today, over $50 \%$ of the housing on the City-owned portion of the neighbourhood is nonmarket (Ley, 2019).

Key specific planning principles included neighbourhood enclaves, a pedestrian activity focus, intercommunity public transit, adaptable communities, reference points, and local shops

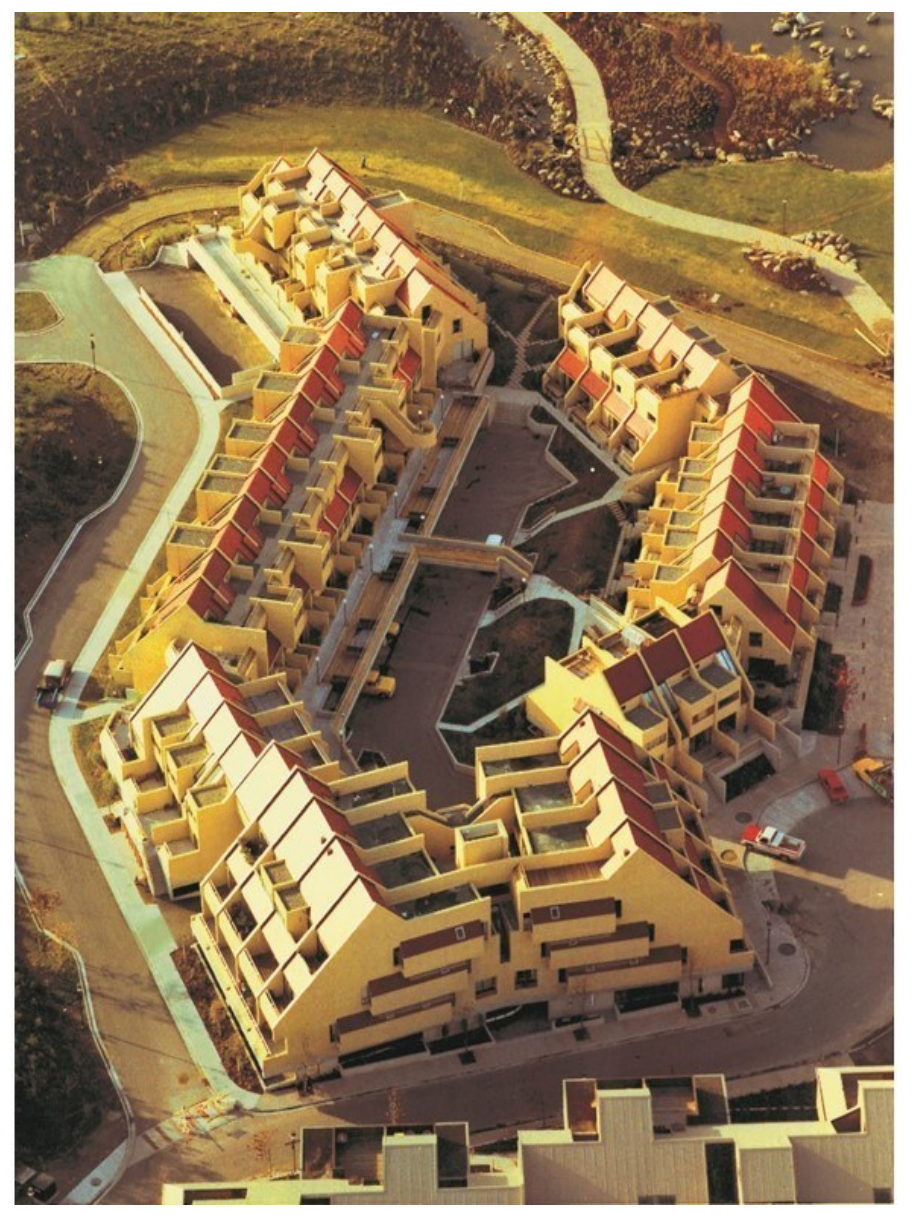

Figure 6. Example of an enclave under development (Source: Henriquez Architects, with permission) 

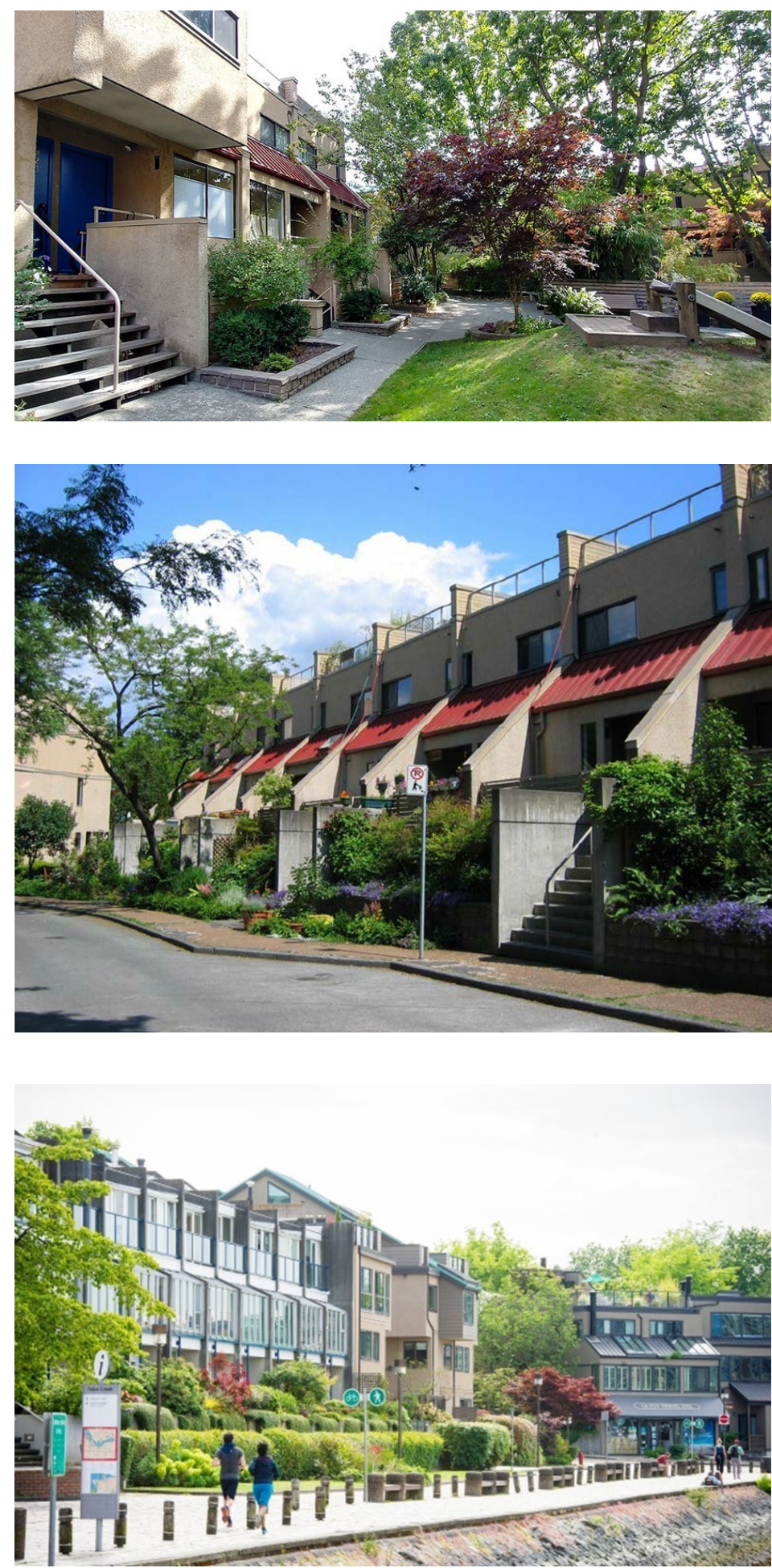

Figure 7, 8, 9. The Built Environment of False Creek South (Source: The City of Vancouver, with permission) every 1500 feet (457 metres) where possible (City of Vancouver Planning Department, 2017). ${ }^{6}$ The enclaves were to be nested areas: clusters of buildings with central courtyards with an inward focus approximately 457 metres (1,500 feet) in diameter and with populations of up to 700 people. These were intended to provide both a certain measure of privacy and territorial space for the residents living in them, but also a focal point for social interaction (Thompson, Berwick, Pratt \& Partners, 1974).

The focus of the neighbourhood was on the pedestrian realm with linked pedestrian spaces which were intended to promote communal interaction and avoid domination by cars. As resident, Rider Cooey says (as cited in Ball, 2013)., "[w]e were basically an experiment [in using] fewer cars." Pedestrians were to be afforded reference points - pleasing natural vistas every few minutes both as a navigational aid and for aesthetic purposes. Public transit was intended to be in place before people started moving in so that they would not have to rely on their vehicles to access other parts of the city. Indeed, cars do not dominate and are stored underneath most of the buildings, further street-taming has occurred in recent years, and an adjacent light-rail transit station was opened in time for the 2010 Olympics and remains in place. The neighbourhood was also laid out in a fashion that enabled it to accommodate new growth and change in the future, and all residents were to be easily able to access local shops which were to be "seeded" throughout the neighbourhood (Ball, 2013).

The heart of the green space is comprised of the diverse environments of Charleson Park and a seawall that connects to Granville Island extends to the west and to the newer neighbourhood of Southeast False Creek/Olympic Village to the east. Charleson Park is unusual in that it has a forested berm to protect parts of the neighbourhood from the noise of a busy arterial (Sixth Avenue), a waterfall (from city water sources), an engineered stream, a

\footnotetext{
${ }^{6}$ There were many more at a variety of scales, but too many to consider here (For more detail, see Thompson Berwick and Pratt and Partners, 1974).
} 


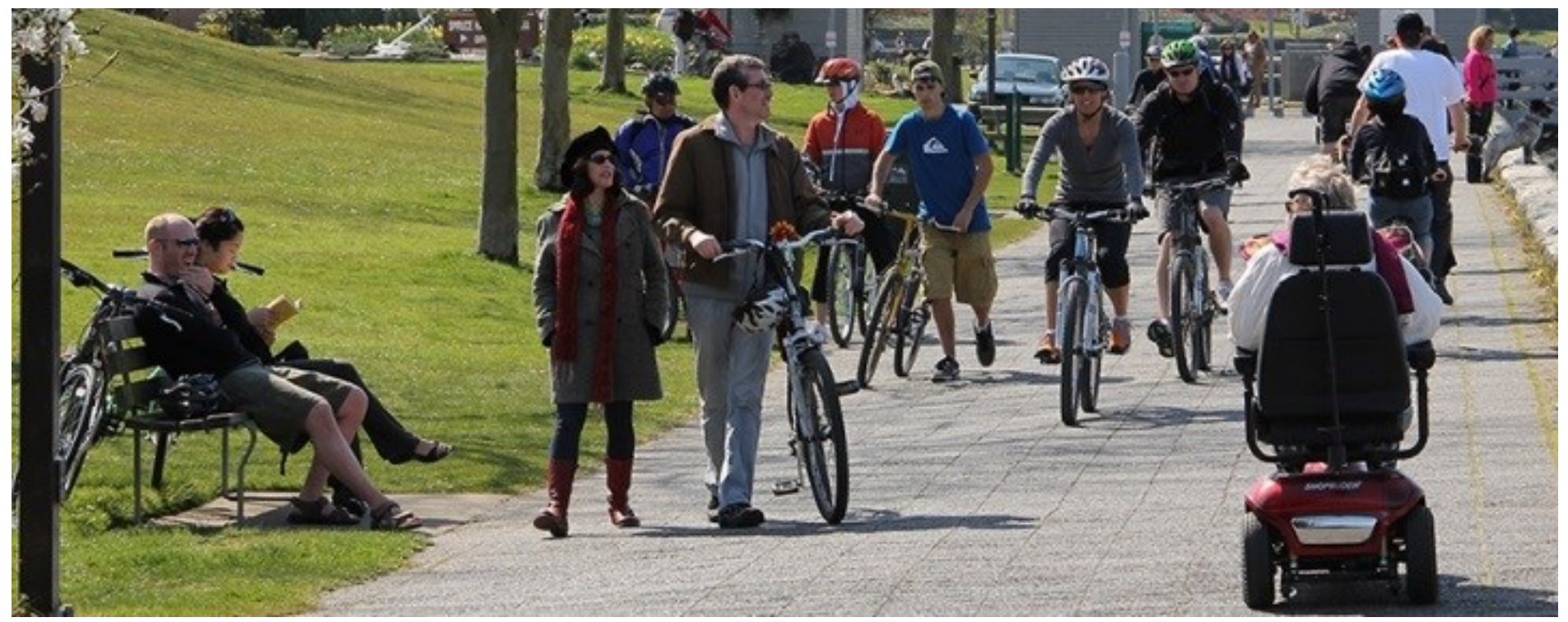

Figure 10. False Creek South Seawall (Source: City of Vancouver, with permission)
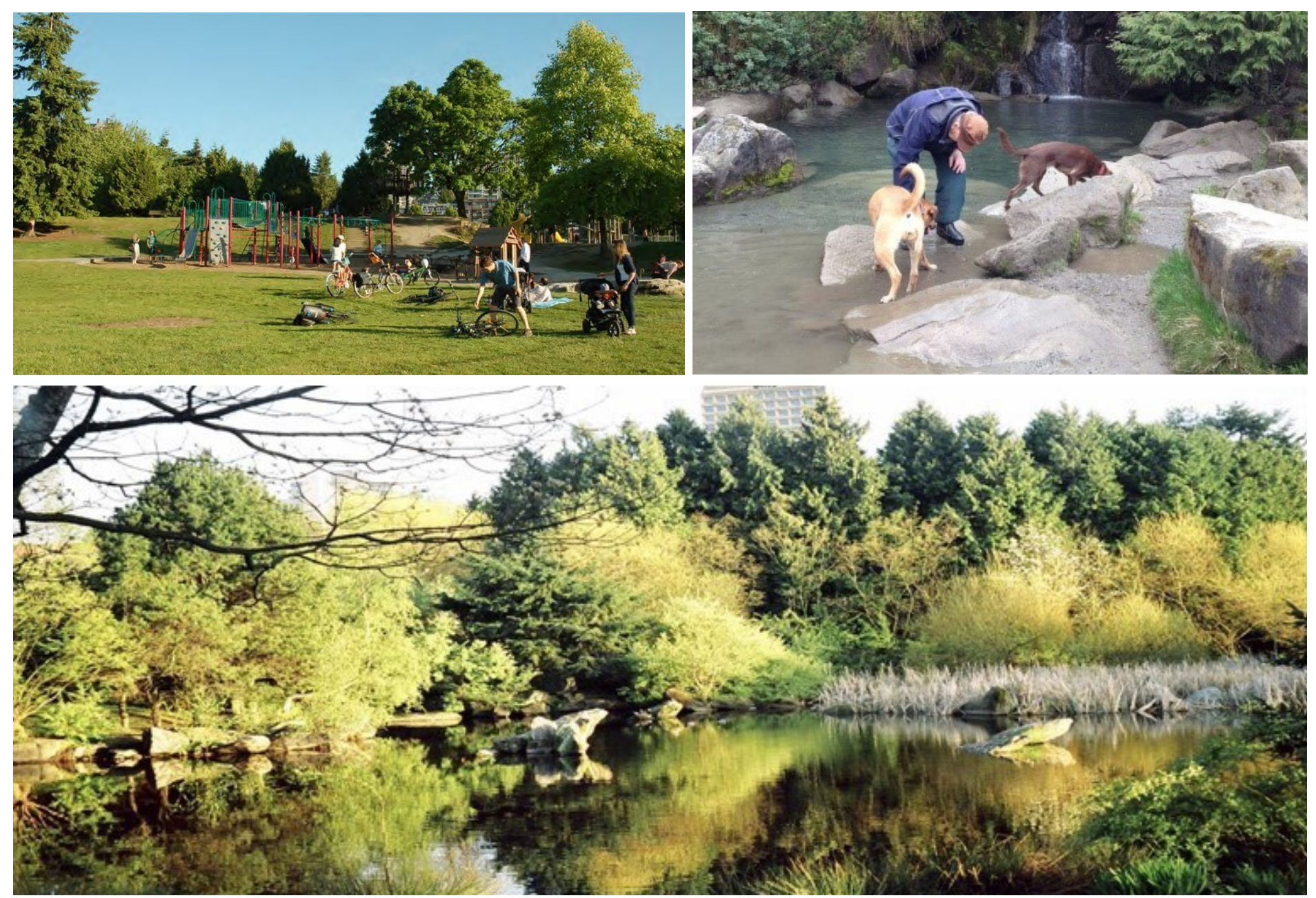

Figures 11, 12 and 13. Charleson Park (Source: Top-left and bottom: City of Vancouver, with permission; Top-right: Author's photo) 


\section{Lessons of Success from False Creek South and Granville Island}

wildlife pond, as well on-leash and off-leash dog areas, a kids' playground, picnic areas, and a community garden. The park is also connected by a vegetated walkway over Sixth Avenue to the adjacent neighbourhood of Fairview.

\section{Undivided Ownership of Land}

Relatively undivided ownership of land also proved to be an important factor in both Granville Island and False Creek South's success. In the case of Granville Island, the federal government was the sole owner of the land. Until 1973, administration of the Island was the responsibility of the National Harbours Board. After the plan for the area's redevelopment was approved, control of the Island was transferred to CMHC (Gourley, 1988). A Granville Island Trust, comprised of local stakeholders, was established to manage the Island's affairs. While nominally under the control of CMHC, day-to-day management (right down to a detailed level) was largely left to the Trust. Over time, the Trust's role was relegated to a strictly advisory role and has now been transferred to a multi-stakeholder Granville Island Council (Lippa, personal communication, December 18, 2019; Bramham, 2014b).

At the time that the proposal to redevelop Granville Island as a market and arts precinct was first mooted, the City of Vancouver wanted the Island to be a typical "greenfield" park (Gourley, 1988). When it realized that was not going to happen, it gave approval for what the Trust and CMHC had in mind by adopting the Granville Island Reference Document, a set of planning and development guidelines for the Island (City of Vancouver, 1978). Had it become just another "park," an enormous opportunity would have been wasted to create something truly innovative. The fact that $\mathrm{CMHC}$, with the support of the federal government, was able to develop what it did without major interference by other jurisdictions was a huge factor in its success. Of course, if CMHC's plans had been misguided, there would have been little opportunity to steer things in a different direction. For example, under the Stephen Harper government, media reports emerged of talks between $\mathrm{CMHC}$ and Port
Metro Vancouver exploring the potential for a transfer of management. Once this information became known, there was significant community pushback, including from then-mayor Gregor Robinson, with the talks ultimately breaking off (Jackson, 2014).

When the City of Vancouver undertook the redevelopment of False Creek South, it was aided by the fact that it owned over $80 \%$ of the land, a total of 44 out of 55 hectares (Hulchanski, 1984). After it was expropriated from First Nations (Roy, 2009; Maracle, 2005), two massive land grants were given by the province in 1886 to the Canadian Pacific Railway (CPR), on both sides of False Creek. This extended north into the future downtown and south almost as far as the Fraser River as an inducement for making Vancouver the terminus for the national railway (MacDonald, 1977).

By the 1920s, False Creek South, along with Granville Island, was a heavily industrialized area with 10,000 employed workers (Ley, 2019). In the meantime, CPR gradually sold off lots on both sides of the Creek. When it was decided in the 1960s to shift land use priorities, the province in 1968 gave CPR new land on the north shore of False Creek in exchange for its remaining 14 hectares (35 acres) holdings on the south shore. The province then flipped the land to the City in exchange for land the latter owned in the neighbouring municipality of Burnaby, which then became the site for Simon Fraser University (Gourley, 1997; Challis, 1972). This made it possible to develop a land use plan for the neighbourhood and to implement innovative ideas as to how it should be laid out since the City was now the primary owner and did not have profitmaking as its principal objective. In essence, the City was working with a "blank slate," but with a very different vision than Le Corbusier and the modernists.

The neighbourhood was to be characterized by a revolutionary formula of one-third upper-income, one-third middle-income, and one-third lowerincome, and with a rich assortment of tenure types: co-ops, strata, social housing and affordable rentals 


\section{Lessons of Success from False Creek South and Granville Island}

(City of Vancouver Planning Department 1974; Thompson, Berwick, Pratt \& Partners, 1974). It was also intended to be family-oriented as evidenced by the fact that $65 \%$ of the units in the neighbourhood are two bedroom or more, and $37 \%$ of the family units have at-grade access (Hardwick, 1984; Hulchanski, 1994). While there has been some upward drift in income over the years, it has largely cleaved to the original vision of one-third upper, one-third middle, and one-third lower (City of Vancouver Planning Department, 2017; Vischer Skaburskis Planners, 1980).

Moreover, Ley (2019) has attributed such upward drift as has occurred to residents "aging in place" and reaching their earning peak rather than being the result of gentrification. As Beasley (2019) notes, the City was able to afford the one-third, one-third, one-third formula by keeping the land in leasehold, rather than selling it off to the private sector. This kept the land component of the development costs lower than they would have been otherwise. However, the downside is that, as we are seeing today, residents are struggling under the weight and uncertainty of not being able to renew their leases.

Currently, a number of long-term leases from the 1970s are on the verge of expiring, and even strata owners and co-ops whose expiry date is some way off are experiencing difficulty in getting loans for renovations and remortgaging their properties because of tenure uncertainties (Ball, 2013; Fumano, 2019). *RePlan was originally formed in 2010, as a committee of the False Creek South

\section{Household Income Mix}

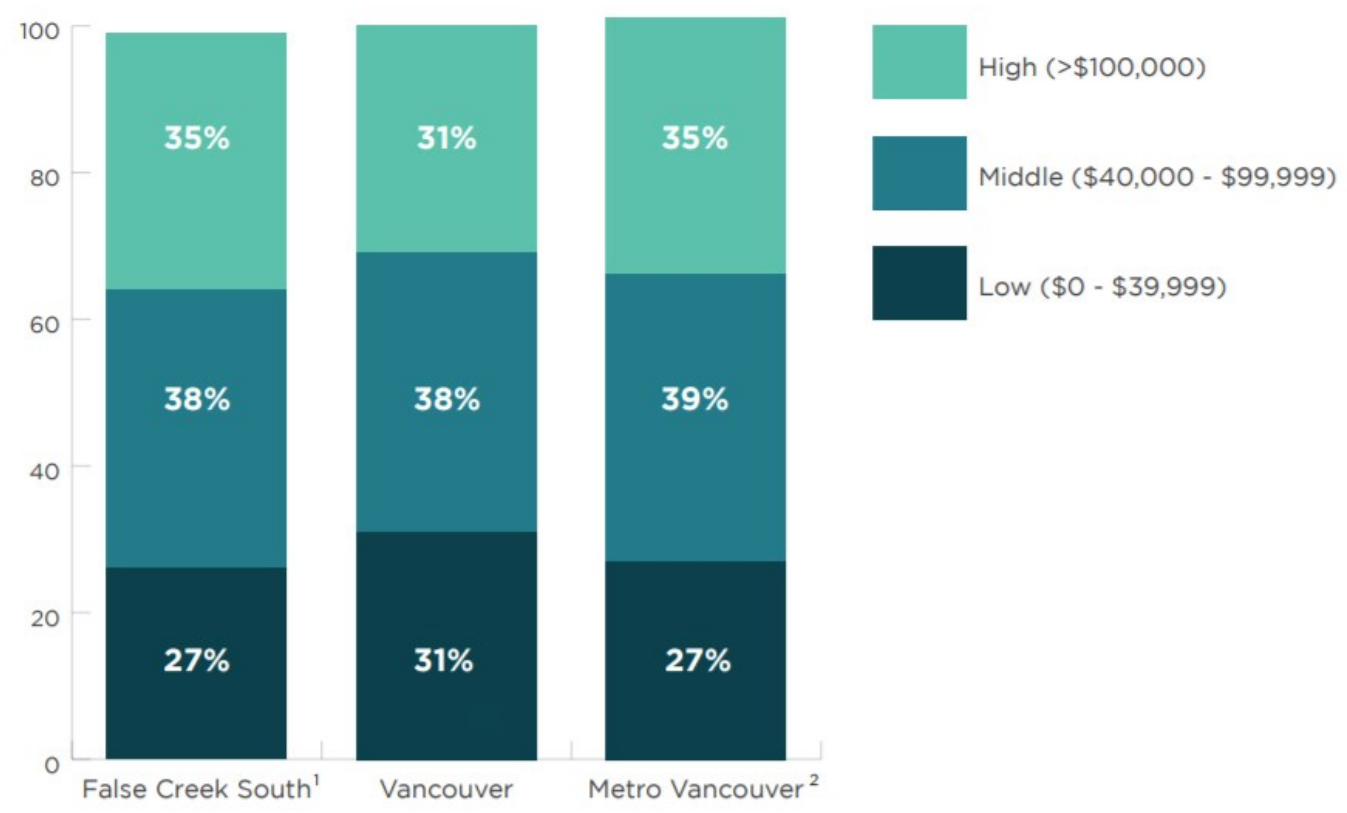

1 Based on Census Tract 0049.02

2 Metro Vancouver based on Greater Vancouver, Regional District [Census division]

Source: 2016 Statistics Canada Census data

Figure 14. Comparative 2016 Household Income Graph for False Creek South (Source: City of Vancouver Planning Department, 2017, with permission) 


\section{Lessons of Success from False Creek South and Granville Island}

Neighbourhood Association to fight for the renewal of the leases and to proactively seek to initiate the development of a new community plan. Former city planners and local architects have come to its assistance, including one who was instrumental in the planning for the Southeast False Creek/ Olympic Village development and Concord Pacific on the north shore of the Creek. With the template of the much higher-density Concord Pacific/ Yaletown staring at them from across the Creek, the fear was that at least part of the City bureaucracy wanted to use the lease expiries to move existing residents out and build towers in their place which would be extremely lucrative for the City or, alternatively, to drastically increase the lease rates which would force many existing residents to leave (Ball, 2013; Bramham, 2014a).

In 2018, *RePlan and the City's Planning Department reached consensus on a set of principles to help guide a new community planning process for the next decades of the neighbourhood's evolution. Given the need to resolve the land lease issue (many were on the verge of expiring), it was decided to pause planning until substantial progress had been made on the lease front. After close to seven years of ongoing negotiations with the City, not a single new lease has been signed, which *RePlan planner, Nathan Edelson attributes to bad faith on the City's part (personal communication, December 3, 2020).

\section{Experimenting with New Planning Approaches}

A crucial factor in the success of these developments was the willingness to experiment with new planning approaches. In a way, Granville Island, though lacking a residential component except for houseboats, was new urbanism fifteen years before new urbanism became a watchword. The Project for Public Spaces (2009) notes that Granville Island "is a first-class example of how a great district can emerge, even in the most unlikely location, because local people identified the area's potential and worked hard to create vital public spaces. The Island's status as one of Vancouverites' favorite spots isn't due to some ingenious stroke of master planning, but to the steady, patient progress of local organizations and businesses." In this process, planners emphasized preserving the existing industrial vernacular of the Island, which involved repurposing existing buildings or ensuring that new buildings respected the "design code" of the old.

As Gourley (1988, p. 73) notes, "[t]he designers found a rich pattern in the island's ramps, surviving rail tracks, loading docks and alleyways, and carried their design guidelines out into the streets. The hardware of post and lintels, steel pipes, bollards and awnings were carefully chosen to fit the character of the entire island." While the industrial structures of False Creek South were torn down, streets, closes, and squares were named after past in situ industrial activities or other historical references, thus maintaining some sense of historical continuity (Ley, 2019).

In contrast with a mania for single-use zoning found elsewhere, Granville Island's planners insisted on a mix of land uses. A couple of the old industries were retained, including a cement plant and a shipbuilding and repair enterprise, along with the new elements - the public market, an art college, shops, theatres, a brewpub, hotel, waterpark, and arts and crafts studios (Meuse, 2017). In addition, there is a greenfield park, and plazas where people can gather, eat, and listen to buskers. The plan also prioritized pedestrians and cyclists over cars and, except for a one or two restaurants that moved in before the Island was rebranded, there are no chain outlets. Moreover, all attempts to introduce them have been firmly resisted.

In the case of False Creek South, the City chose to involve citizens in "owning" the neighbourhood from the very beginning. In a design exercise involving hundreds of citizens and led by then University of British Columbia architecture professor, Stanley King, students and community members, produced and evaluated drawings that greatly influenced the eventual shape of the neighbourhood (Bramham, 2011; City of Vancouver Planning Department, 2017). The City also established a False Creek South Neighbourhood Association, and housing co-op 


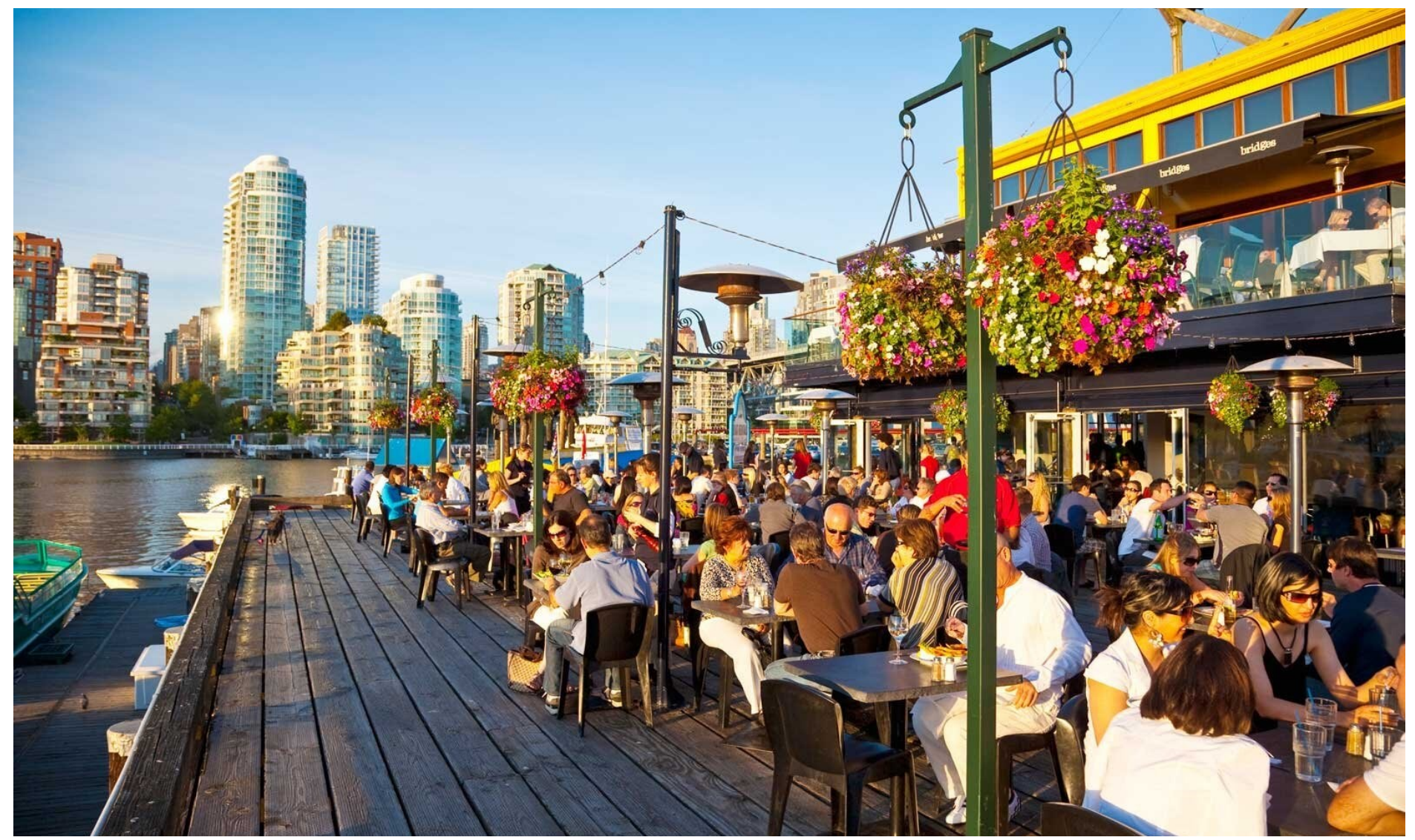

Figure 15. Granville Island (Source: Travel and Lesure.com, with permission)

members have played an important role in its evolution. Each tenure type was to have designated seats on the Association; a regrettable omission was the lack of seats for non-market rentals (Ball, 2013). There was also a community newspaper for decades (Ball, 2013), and currently there is an on-line community website and newsletter (www.falsecreeksouth.org) which is also a vehicle for spreading information about the ongoing work of *RePlan and other community news.

\section{SHORTCOMINGS}

One area where False Creek South has not fully succeeded is in ensuring mixed use. Originally, every resident was supposed to be within 457 metres (1,500 feet) of a store (Vancouver, 2017; Punter, 2003). There is a small commercial district in Leg-in-Boot Square, but its grocery store is gone and the other stores provide largely non-essential services. Moreover, the square itself has never come to life, but is rather a dead zone because residents in the adjacent multi-storey building were concerned about noise and planners were skeptical about the square's commercial potential (Ball, 2013). There used to be two strip malls across Sixth Avenue, one of which had an excellent independent grocery store, but the mall was demolished to make way for expensive condominiums, and other strip mall has limited amenities. Apart from a convenience store further west there are no other stores in the neighbourhood.

While a number of the original businesses have failed (City of Vancouver Planning Department, 2017), Granville Island remains a source of fresh food and new commercial nodes have emerged in the nearby neighbourhood of Southeast False Creek/ Olympic Village and along Cambie Street up

\footnotetext{
${ }^{7}$ Granville Island is also where the neighbourhood's community centre is located.
} 


\section{Lessons of Success from False Creek South and Granville Island}

to Broadway Avenue West. ${ }^{7}$ The failure to achieve a stronger commercial component in the mixed spectrum may also be linked to planners' decision to abandon the traditional grid in the neighbourhood.

Another weakness is that the enclaves have not necessarily provided the right mix of privacy and conviviality as was hoped. Some residents have suggested that they want more privacy than the enclaves afford, nor do they seem to be the social gathering spaces they were intended to be (Vischer Skaburskis Planners, 1980; Vischer, 1986). Nonetheless, the pedestrian orientation of the neighbourhood guarantees serendipitous encounters with neighbours and acquaintances, something often remarked upon by residents.

Despite these flaws, both False Creek South and Granville Island have proven far more successful than their critics had anticipated. They are emblematic of what planners can achieve in the right circumstances if they reject the neoliberal doctrine that government cannot successfully act as a developer and if planners have faith in their abilities, rather than giving pride of place to market forces. Politicians made the innovations in these two cases possible by creating the necessary policy room, but it was the individual architects and planners, such as such as Thompson, Berwick, Pratt \& Partners, Hotson Bakker Architects, Gregory Henriquez, and Stanley King, who filled the containers.

\section{CONCLUSION}

At the outset, I defined "success" in terms of attaining one or more the following conditions: the achievement of socio-economic diversity; the achievement of abundant affordable housing; successful mix of uses; an abundance of amenities, such as green space and public space; opportunities for community interaction, and at least some continuity of historical architectural forms.

Granville Island features an unusual mix of land uses, attracts people from all walks of life, has green and public space in abundance (including a waterpark for kids), many arts and crafts studios, as well as theatres and performance spaces - with the centrepiece of a public market - and attracts people from all over the region and from out-of-town during the tourist season. Its distinctive sense of place derives from having maintained its industrial heritage vernacular.

False Creek South exhibits more socio-economic diversity than probably anywhere else in the city. Over $50 \%$ of its housing is considered "affordable," and this takes a variety of forms - social housing, cooperative housing, and affordable rentals, in addition to condominiums. Its attempts to integrate mixed use have not been very successful. However, this is offset by the adjacency of shopping opportunities in Granville Island, Southeast False Creek, the Cambie Corridor, and on Broadway. It has an abundance of green space and open space, including Charleson Park and the seawall.

In addition, False Creek South has always enjoyed a strong sense of community with annual community picnics, a strong community association, and an organization that acts as a planning liaison with the City. Finally, while traces of industrial structures were eliminated when the neighbourhood was redeveloped, historical activities are echoed in the names given to streets and other features.

So overall, in my view, Granville Island and False Creek South have been resounding success stories, though False Creek South is currently struggling for its survival in the face of lease renewal issues (Fumano, 2019). Granville Island, for its part, remains a major local and tourist attraction in B.C., attracting over ten million visitors a year (Bramham, 2014b), and False Creek was awarded the "best neighbourhood" award in Vancouver (Vancouver Magazine, 2016). Key factors in their success include an era where innovative approaches were embraced; visionary politicians and champions were on the scene who provided the necessary leadership and advocacy; interjurisdictional cooperation existed between the three levels of government; a shift in planning priorities occurred; government ownership of most or all of the land base was present; planners and architects were willing to try

\section{Canadian Planning and Policy 2021}




\section{Lessons of Success from False Creek South and Granville Island}

new concepts and planning tools, and there was strong citizen support and "ownership" of the resulting product.

Like all real-world examples, these developments were subject to the usual push-pull factors of day-to -day politics but still managed to achieve a high standard. Amongst the reasons they would be hard to replicate today are the extraordinary rise in Vancouver land values; as Ley (2019) says, False Creek South was a "made in Canada" development; today's developments are "made in a globalized world," where domestic and offshore profit-seekers dominate the real estate and development markets. A second reason is that population growth from inmigration necessitates higher-density development even as single-family neighbourhoods resist taking on their share of that density. Ironically, False Creek South was considered outrageously dense in its day; today it is considered positively pastoral and unrealistic (Ball, 2013; Ley, 2019).

Fortunately, the affordable housing crisis in the Vancouver region may once again be forcing governments at all levels to look at creative solutions. For instance, the City of Vancouver - in partnership with the Co-operative Housing Federation of B.C. - has created a Community Land Trust (CLT) on City-owned land in South Vancouver that provides security of tenure for new residents, both in co-ops and other forms of tenure (Kaufman, 2018) on 99-year leases. It features a total of 1,039 units, with two housing co-operatives (City of Vancouver, 2020; Kaufman, 2018). The buildings will be designed, built, financed and maintained by the Vancouver Community Land Trust, a non-profit organization established by the Cooperative Housing Federation of B.C. The City leased this piece of land, worth $\$ 130$ million, to the Trust for the sum of $\$ 10.00$ (Bula, 2017). However, according to Edelson (personal communication, December 3, 2020), the project involved minimal public consultation and was imposed in an essentially top-down way. Despite this shortcoming, * RePlan has proposed transforming Southeast False Creek into a Community Land Trust and, if the City were to go along with it, that would represent another major leap in the evolution of the area as a node of creative planning (Bula, 2017).

Provincially, the New Democrats have proposed to build 114,000 affordable housing units over a tenyear period from 2017 to 2027, with some of these being co-op housing units. Specific numbers, however, are scarce, and commitments are contingent on matching funds from the federal government and municipal governments providing building sites (Clancy, 2017). On the federal level, the Liberal government in 2018 launched a National Housing Strategy that makes some provision for new co-ops and affordable rentals funding. However, specifics are scarce (Canada Mortgage and Housing Corporation, 2018). Affordable housing is also mentioned in the September 2020 Throne Speech, but without details (National Post, 2020). In terms of renovating False Creek South, including renegotiating old leases, the situation has been stalemated for years, despite the willingness of *RePlan to embrace neighbourhood change. Nathan Edelson (personal communication, December 3, 2020) attributes this paralysis to different parts of the City bureaucracy working in silos, pursuing incompatible mandates and agendas.

By contrast, Granville Island is grappling with the changes that the last forty years have wrought and is stepping boldly into the future with its Granville Island 2040 Plan - seeking to build closer ties with local First Nations, improve access to the Island, expand the public market, further embrace arts and innovation, and restore and sustain the public realm (Canada Mortgage and Housing Corporation, 2017). ${ }^{8}$ Like * RePlan with respect to False Creek South, the Granville Island Council wants to retain what works with the Island while reinventing it for the coming decades. If only the City of Vancouver

\footnotetext{
${ }^{8}$ As the result of COVID-19, the Granville Island Council has decided to pause the 2040 Plan and to close the Public Market. For the first time in over forty years, it has had to ask the federal government for emergency funds to keep some of the smaller businesses afloat. However, the Arts Umbrella has nearly finished repurposing major parts of the old arts college facility, and will be ready to open once COVID-19 restrictions are lifted.
} 
were as visionary when it comes to a neighbourhood that is one of the most successful in North America. Hopefully, City politicians and bureaucrats will eventually come to their senses ...9

\section{ACKNOWLEDGMENTS}

The author wishes to thank Ray Tomalty, Christine Krumrey, David Gordon, Gina Fung, and unnamed reviewers

\section{Corresponding Author}

Don Alexander

Vancouver Island University

E-mail: don.alexander@,viu.ca

\section{REFERENCES}

Adams, N. (1972, June 24). Housing or a Park for False Creek. Vancouver Sun, p. 6.

Alexander, C. (1969). Cells for subculture. Berkeley, CA: Center for Environmental Structure.

Alexander, C., Ishikawa, S., \& Silverstein, M. (1977). A pattern language: Towns, buildings, construction. Oxford, UK: Oxford University Press.

Alexander, D. (2019). Remembering the legacy of Shirley Chan: Saving Vancouver's Chinatown neighbourhood. Planning West, 61(1), 12-14. https://doi.org/10.25316/IR$\underline{4290}$

Atlas Obscura. (2014). "Giants" on Granville Island Silos Vancouver, British Columbia.

Ball, D. (2013, December 31). False Creek South: An Experiment in Community. The Tyee.

Beasley, L. (2019). Vancouverism. Vancouver, BC: UBC Press.

Bramham, D. (2011, September 17). False Creek South: It's near perfect and it's mine. Vancouver Sun, p. A2.

Bramham, D. (2014a, June 23). Residents worry about False Creek South's future. Vancouver Sun, p. A1.

Bramham, D. (2014b, July 10). Let's save Granville Island from the Bureaucrats. Vancouver Sun. Vancouver Sun, p. A4.

Bramham, D. (2015, September 18). Granville Island Needs Another Alan Clapp. Vancouver Sun, p. A4.

Bula, F. (2017, February 16). How community land trusts could help build affordable Vancouver housing. Globe and Mail. Retrieved from

Canada Mortgage and Housing Corporation. (2017). Granville Island 2040: Bridging Past and Future. Vancouver, BC: CMHC.

Canada Mortgage and Housing Corporation. (2018). National Housing Strategy: National Housing Co-investment Fund.

Challis, L. (1972). False Creek: Data sheets on development. Vancouver, BC: Vancouver Planning Department.

Chan, K. (2017, September 8). 19 photos of Emily Carr University's new False Creek Flats campus. Daily Hive.

Chan, K. (2019, November 5). Squamish Nation planning 6,000 new homes next to Burrard Bridge. Daily Hive.

CityHallWatch. (2014, September 28). Past Vancouver City Councils (Mayors and Councillors) going back to 1886.

City of Vancouver. (1974). False Creek and Area Official Development Plan. Vancouver, BC: City of Vancouver Planning Department. 


\section{Lessons of Success from False Creek South and Granville Island}

City of Vancouver. (1987). Reference Document for Granville Island False Creek-Area 9 [Land Use and Development Policies and Guidelines]. Vancouver, BC: City of Vancouver Planning Department.

City of Vancouver. (2020). Dunbar-Southlands Neighbourhood Social Indicators Profile 2020. Vancouver, BC: Social Policy and Projects Division.

City of Vancouver Planning Department. (1989). Evaluation of False Creek South social objectives. Vancouver, BC: City of Vancouver.

City of Vancouver Planning Department. (2017). False Creek South Community Profile 2017. Vancouver, BC: City of Vancouver.

Clancy, N. (2017, May 2). FACT CHECK: NDP plan to build 114,000 homes in 10 years "incredibly unrealistic" say critics. $\underline{C B C N e w s}$.

Condon, P. (2020, January 3). Vancouver Looks Poised to Sell off False Creek South. The Tyee.

Friendly, A. (2016). National Urban Policy: A Roadmap for Canadian Cities. In IMFG Perspectives (No. 14). Toronto, ON: Institute on Municipal Finance and Governance.

Fumano, D. (2017, June 2). High-Density Doomsday Prediction Proved False: Socially Mixed False Creek South Surpassed Expectations to Become Model Community. Vancouver Sun, p. 1.

Fumano, D. (2019, June 25). Frustration and fear in one of Vancouver's most lauded, livable communities. Vancouver Sun, pp. A1, A2.

Gourley, C. (1988). Island in the creek: The Granville Island story. Madeira Park, BC: Harbour Publishing.

Gourley, C. (1997). False Creek. In C. Davis (Ed.), The Greater Vancouver Book: An Urban Encyclopedia. Surrey, BC: Linkman Press.

Hall, P. (2014). Cities of tomorrow: An intellectual history of urban planning and design since 1880 (4th ed.). Hoboken, NJ: Wiley-Blackwell.

Hardwick, W. G. (1994). Responding to the 1960s: Designing Adaptable Communities in Vancouver. Environment and Behavior, 26(3), 338-362. https:// doi.org/10.1177/001391659402600303

Hodge, G., Gordon, D. L. A., \& Shaw, P. (2014). Planning Canadian communities: An introduction to the principles, practice, and participants (7th ed.). Toronto, ON: Nelson .

Hulchanski, J. D. (1984). St. Lawrence and False Creek: A Review of the Planning and Development of Two New Inner City Neighbourhoods. (SCARP Working Paper Series No. 10). Vancouver, BC: School of Community and Regional Planning.
Hulchanski, J. D. (1986). An affordable alternative to owning or renting: Canada's non-profit co-operative housing program (a paper prepared for World Planning and Housing Congress, Adelaide, Australia. Vancouver, BC: School of Community and Regional Planning.

Jackson, E. (2014, July 4). Mayor to Port Metro Vancouver: Hands off Granville Island. Vancouver Metro, p. 1.

Jacobs, J. (1961). The death and life of great American cities. New York: Vintage Books.

Kaufman, R. (2018, May 7). Community Land Trust Model Taking Off in Vancouver. Next City.

Ley, D. (1987). Styles of the times: Liberal and neoconservative landscapes in inner Vancouver, 1968-1986. Journal of Historical Geography, 13(1), 40-56. https:// doi.org/10.1016/S0305-7488(87)80005-1

Ley, D. (2014). Modernism, post-modernism and the struggle for place. In J. A. Agnew \& J. S. Duncan (Eds.), The power of place: Bringing together geographical and sociological imaginations (pp. 45-65). London, UK: Routledge.

Ley, D. (2019, April). Can False Creek South remain a model community in a changing world? Public talk sponsored by the False Creek Neighbourhood Association and *RePlan, presented at Vancouver, BC.

MacDonald, N. (1977). The Canadian Pacific Railway and Vancouver's Development to 1900. BC Studies: The British Columbian Quarterly, (35), 3-35. https:// doi.org/10.14288/bcs.v0i35.936

Magnusson, W., \& Sancton, A. (1983). City politics in Canada. Toronto, ON: University of Toronto Press.

Maracle, L. (2005). Goodbye, Snauq. In Our story (pp. 205219). Toronto, ON: Dominion Institute and Anchor.

McGarva, G., \& Hein, S. (2021, February 25). As City Signals False Creek South Is Up for Grabs, Here's a Homegrown Plan. The Tyee.

Meuse, M. (2017, March 13). How Granville Island changed the course of Vancouver urban design history. $C B C$ News.

National Post. (2020, September 23). Read full text of Liberal government's 2020 throne speech delivered by Julie Payette. National Post.

Petit Gourmet. (2016, October 11). Granville Island Public Market.

Phillips, R. (1993). The evolution of an urban village. Cascadia Forum, 1(1).

Project for Public Spaces. (2009, January 1). Granville Island: One of the World's Great Places.

Project for Public Spaces. (2015, January 7). Granville Island Aménagement et politique au Canada 2021 
Lessons of Success from False Creek South and Granville Island

Public Market.

Punter, J. (2003). The Vancouver Achievement: Urban

Planning and Design. Vancouver, BC: UBC Press.

*RePlan. (2016). The False Creek South Housing Cooperatives Story.

Roy, S. (2009). Mapping Tool: Kitsilano Reserve.

Sandercock, L. (1998). Towards cosmopolis: Planning for multicultural cities. Chichester, NY: John Wiley.

Smedman, L. (2013, April 11). Yaletown: The neighbourhood at a glance. Vancouver Courier.

Spaxman, R. (1994). The planning of South False Creek. Plan Canada, 34(4), 76-77. https://doi.org/10.25316/IR-4666

St. Denis, J. (2019, December 29). No more free parking at Granville Island hasn't deterred most Vancouverites: Poll. CTV News.

Thompson, B. (MTR Consultants). (n.d.). Environmental improvements with urban development: False Creek, Vancouver, Canada. Ottawa, ON: Canada Mortgage and Housing Corporation.

Thompson, Berwick, Pratt \& Partners. (1974). False Creek proposals, working papers: Volume 1, patterns.

Vancouver, BC: City of Vancouver Planning Department.

Vancouver Heritage Foundation. (2018). Granville Island.

Vancouver Magazine. (2016, March 21). Vancouver's Best Neighbourhoods 2016. Vancouver Magazine.

Vischer Skaburskis. (1980). False Creek area 6 phase 1 postoccupation evaluation (2 vols.). Ottawa, ON: Canada Mortgage and Housing Corporation.

Vischer, J. (1986). Social mix and environmental design: Exploration of a contemporary concept. Journal of Architectural and Planning Research, 3(4), 315-326.

Weaver, J. (2014). Urban reform. In The Canadian Encyclopdia. 